\title{
Sistem Pakar Untuk Mendeteksi Kerusakan Komputer Dengan Metode Forward Chaining
}

\author{
Kusmayanti Solecha ${ }^{1}$, Jefi $^{2}$, Hendri ${ }^{3}$, Enoh Badri ${ }^{4}$, Ali Haidir ${ }^{5}$ \\ 1,2,5 Universitas Bina Sarana Informatika, \\ e-mail: ${ }^{1}$ kusmayanti.ksc@bsi.ac.id, ${ }^{2}$ jefi.jfi@bsi.ac.id, ${ }^{5}$ ali.alh@bsi.ac.id \\ ${ }^{3,4}$ Universitas Nusa Mandiri, \\ e-mail:, ${ }^{3}$ hendri.hed@nusamandiri.ac.id

\begin{tabular}{ccc}
\hline Diterima & Direvisi & Disetujui \\
$01-12-2021$ & $10-12-2021$ & $11-12-2021$ \\
\hline
\end{tabular}

\begin{abstract}
Abstrak - Sistem pakar merupakan cabang dari kecerdasan buatan dan juga merupakan bidang ilmu komputer. Sistem ini bekerja untuk mengadopsi pengentahuan manusia ke komputer yang menggabungkan dasar pengetahuan (knowledge base) dengan sistem inferensi untuk mengantikan fungsi seorang pakar dalam menyelesaikan suatu masalah. Saat ini seorang teknisi Komputer membutuhkan waktu lama dalam mendiagnosa kerusakan yang terjadi pada sebuah komputer, bahkan sering kali teknisi menunda pekerjaannya hanya untuk menghasilkan solusi dari kerusakan komputer. Untuk mangatasi masalah tersebut, maka dirancang suatu sistem pakar untuk mendeteksi kerusakan komputer sistem pakar ini menggunakan metode Forward Chaining dengan menggunakan basis database yang disusun kedalam berbagai tabel dalam suatu aturan agar seorang pakar dan pengguna dapat mengambil kesimpulan dari apa yang sudah didiagnosa oleh sistem pakar ini. Sistem pakar ini dibuat sebagai alat bantu seorang pakar dan pengguna dalam mendiagnosa kerusakan komputer dari analisa menurut seorang praktisi dan media internet. Sistem pakar ini akan menampilkan pertanyaan yang kemudian akan dipilih dan dijawab oleh penggunasampai program menemukan solusi dari diagnosa yang telah dilakukan pada sistem pakar ini. Selain itu sistem pakar ini dilengkapi dengan informasi kerusakan komputer.
\end{abstract}

Kata Kunci: Forward Chaining, Kerusakan Komputer, Sistem Pakar

\begin{abstract}
Abstrak - Expert systems are a branch of artificial intelligence and are also a field of computer science. This system works to adopt human knowledge to a computer that combines a knowledge base with an inference system to replace the function of an expert in solving a problem. Currently a computer technician takes a long time to diagnose the damage that occurs to a computer, even technicians often delay their work just to produce solutions for computer damage. To overcome this problem, an expert system is designed to detect computer damage. This expert system uses the Forward Chaining method using a database base that is compiled into various tables in a rule so that an expert and user can draw conclusions from what has been diagnosed by this expert system. . This expert system was created as a tool for experts and users in diagnosing computer damage from analysis according to a practitioner and internet media. This expert system will display questions which will then be selected and answered by the user until the program finds a solution from the diagnoses that have been carried out on this expert system. In addition, this expert system is equipped with computer damage information.
\end{abstract}

Keywords: Forward Chaining, Damage Komputer, Expert System

\section{PENDAHULUAN}

Kemajuan teknologi yang terus berkembang telah banyak merubah bentuk pengolahan data dalam berbagai bentuk usaha manusia dari sistem manual menuju sistem komputerisasi. Terlihat dari sebagian besar manusia yang dalam kesehariannya menggantungkan pekerjaannya kepada teknologi. Semakin kompleksnya informasi yang dibutuhkan, maka banyak pihak yang merasa perlu untuk mengembangkan teknologi serta informasinya sehinggasistem dapat menyelesaikan berbagai masalah sesuai dengan kebutuhan manusia.
Teknologi informasi berbasis sistem komputerisasi telah banyak digunakan dalam berbagai bidang misalnya bidang pendidikan, sosial, bisnis, pemerintahan maupun bidang kesehatan atau pengobatan yang membutuhkan ketelitian dan keakuratan dalam pengelolaan data dan kecepatan dalam mendapatkan informasi yang akurat sehingga dapat diandalkan sebagai sumber informasi.

Perkembangan aplikasi web yang semakin pesat sejak munculnya teknologi internet sangat membantu dalam kemudahan serta kecepatan pengiriman, penyampaian dan penerimaan informasi. Mulai dari perusahaan-perusahaan, 
sekolahan, perguruan tinggi, dan lembaga atau organisasi lainnya telah banyak memanfaatkan aplikasi web dalam kegiatan penjualan, promosi, belajar dan kegiatan lainnya dimana dibutuhkan pengiriman, penyebaran dan penerimaan informasi sehingga memberikan kemudahan bagi pengguna (user) yang membutuhkan.

Menurut Hayadi dalam (Widayanto et al., 2018) "Sistem pakar adalah suatu aplikasi computer yang ditujukan untuk membantu pengambilan keputusan atau pemecahan persoalan dalam bidang yang spesifik".

Menurut Rosnell dalam (Widayanto et al., 2018) menyatakan bahwa "sistem pakar adalah sistem komputer yang ditujukan untuk meniru semua aspek (emulate) kemampuan pengambilan keputusan (decision making) seorang pakar".

Sistem Pakar (expert system) adalah salah satu bidang ilmu Komputer yang mendayagunakan komputer sehingga dapat berperilaku cerdas seperti manusia (Arisandi \& Sari, 2021). Sistem pakar berusaha mengadopsi pengetahuan manusia ke dalam komputer, agar komputer dapat menyelesaikan masalah seperti yang biasa dilakukan oleh para ahli (David, 2017) (Ramadhanu \& Gusrianto, 2021) (Yuswandi \& Prasetyo, 2019).

Saat ini seorang teknisi Komputer membutuhkan waktu lama dalam mendiagnosa kerusakan yang terjadi pada sebuah komputer, bahkan sering kali teknisi menunda pekerjaannya hanya untuk menghasilkan solusi dari kerusakan komputer, seperti kejadian yang saya alami saat terjadi kerusakan pada keyboard komputer yang saya miliki, saya masih harus menunggu beberapa hari untuk mengetahui jenis kerusakan yang terjadi. Begitu juga dengan hasil wawancara dengan teknisi dari beberapa toko komputer dengan rata-rata waktu 15 sampai 20 menit untuk menentukan jenis kerusakan yang terjadi dan itupun belum pasti kerusakannya. Bahkan terkadang teknisi belum pernah mengalami masalah yang sama, sehingga dibutuhkan waktu yang lebih lama untuk menentukan jenis kerusakan dan sekaligus penyelesaiannya.

Gambaran diatas menjadi pertimbangan untuk merancang sistem pakar untuk membantu menyelesaikan kerusakan hardware Komputer dangan metode forward chaining berbasis web, diharapkan dapat membantu memberikan solusi penanganan kerusakan pada Komputer dengan cepat, tepat dan efisien melalui media web namun tidak mengabaikan peran seorang teknisi dan pakar komputer .

\section{KAJIAN LITERATUR}

\section{A. Sistem Pakar}

Sistem pakar merupakan cabang dari AI (Artificial Inteligent) yang membuat ekstensi untuk spesialisasi pengetahuan guna memecahkan suatu permasalahan pada Human Expert. Human Expert merupakan seseorang ahli dalam suatu bidang ilmu pengetahuan tertentu, berarti expert memiliki suatu permasalahan yang tidak dapat dipecahkan oleh orang lain secara efisien (Supartini \& Hindarto, 2016).

\section{B. Forward Chaining}

Forward chaining adalah pendekatan yang dimotori tujuan (goal-driven). Dalam pendekatan ini pelacakan dimulai dari informasi masukan, dan selanjutnya mencoba menggambarkan kesimpulan. Forward chaining mencari fakta yang sesuai dengan bagian dari IF dari aturan IF-THEN (Rismayadi, 2016). Forward Chaining merupakan fakta untuk mendapatkan kesimpulan (conclusion) dari fakta tersebut. Penalaran ini berdasarkan fakta yang ada (data driven), metode ini adalah kebalikan metode Backward Chaining, dimana metode ini dijalankan dengan mengumpulkan fakta-fakta yang ada untuk menarik kesimpulan (Suhendra, Bangun, Aditya, Lestari, \& Yuniawati, 2015). Dengan kata lain, prosesnya dimulai dari facts (fakta-fakta yang ada) melalui proses interface fact (penalaran fakta-fakta) menuju suatu goal (suatu tujuan).

\section{Unified Modeling Language}

Unified modeling language atau (UML) Menurut (Shalahuddin \& A.S., 2014) adalah "bahasa yang banyak digunakan di dunia industri untuk mendefinisikan requirement, membuat analisis dan desain, serta menggambar arsitektur dalam pemrograman berorientasi objek".

\section{Entity Relationship}

Menurut Indrajani dalam (Taufik \& Ermawati, 2017) "Entity yaitu kumpulan objek-objek dengan sifat (property) yang sama, yang diidentifikasi oleh interprise mempunyai eksistensi yang independent" Entitas diberi nama dengan kata benda dan dapat dikelompokan sebagai berikut: nama orang, nama benda, nama lokasi, nama kejadian.

\section{E. Logical Record Structur}

Menurut Friyadie dalam (Taufik \& Ermawati, 2017) "sebelum tabel dibentuk dari field atau atribut entitas secara fisik atau level internal, maka harus dibuatkan suatu bentuk relational model yang dibuat secara logic atau level external dan konsep, dari pernyataan tersebut dibutuhkan yang disebut dengan Logical Record Structure (LRS)".

Dalam pembuatan Logical Record Structure (LRS) terdapat tiga hal yang dapat mempengaruhi, yaitu : one-to-one, one-to-many, many-to-many.

\section{F. Bahasa Pemrograman}

Menurut (Firman et al., 2016) "PHP atau kependekan dari Hypertext Preprocessor adalah salah satu bahasa pemrograman open source yang sangat cocok atau dikhususkan untuk pengembangan 
web dan dapat ditanamkan pada sebuah skripsi HTML. Bahasa PHP dapat dikatakan menggambarkan beberapa bahasa pemrograman seperti C, Java, dan Perl serta mudah untuk dipelajari."

\section{G. Basis Data}

Menurut Yanto dalam (Imron, Afidah, Nurhayati, Sulistiyah, \& Fatmawati, 2019) "Basis data adalah kumpulan data yang saling berhubungan yang disimpan secara bersama sedemikian rupa dan tanpa pengulangan (redundansi), untuk memenuhu berbagai kebutuhan.

\section{METODE PENELITIAN}

Dalam penelitian ini dibagi menjadi beberapa tahapan, diantaranya yaitu: observasi, wawancara, studi pustaka. Pada tahapan pertama adalah tahap observasi, yaitu pengumpulan data pakar dengan mengamati secara langsung atau mendiagnosis gejala dan kerusakan pada Komputer. Tahap kedua adalah wawancara, pada tahapan ini dikulakuakn identifikasi masalah dengan cara mewawancarai mengajukan beberapa pertanyaan seputar gejala dan kerusakan pada Komputer kepada tiga orang pakar yaitu bapak Abdul Aziz Aminudin ST, bapak Agus Setiawan ST, dan bapak Dyan Pra Nugraha ST. Tahapan terakhir adalah studi pustaka mengumpulkan data dengan mengadakan studi penelaahan terhadap buku- buku, literatur-literatur, catatan-catatan, dan laporan-laporan yang berhubungan dengan gejala dan kerusakan pada komputer.

Sistem pakar merupakan cabang dari AI (Artificial Inteligent) yang membuat ekstensi untuk spesialisasi pengetahuan guna memecahkan suatu permasalahan pada Human Expert. Human Expert merupakan seseorang ahli dalam suatu bidang ilmu pengetahuan tertentu, berarti expert memiliki suatu permasalahan yang tidak dapat dipecahkan oleh orang lain secara efisien. (Supartini \& Hindarto, 2016).

Komponen utama pada struktur sistem pakar meliputi Basis Pengetahuan (Knowledge Base), Mesin Inferensi (Inference Engine), Working Memory dan Antarmuka Pemakai (User Interface). Sedangkan untuk metode sistem pakar yang digunakan dengan forward chaining adalah pendekatan yang dimotori tujuan (goal-driven). Dalam pendekatan ini pelacakan dimulai dari informasi masukan, dan selanjutnya mencoba menggambarkan kesimpulan. Forward chaining mencari fakta yang sesuai dengan bagian dari IF dari aturan IF-THEN (Rismayadi, 2016).
Forward Chaining merupakan fakta untuk mendapatkan kesimpulan (conclusion) dari fakta tersebut. Penalaran ini berdasarkan fakta yang ada (data driven), metode ini adalah kebalikan metode Backward Chaining, dimana metode ini dijalankan dengan mengumpulkan fakta-fakta yang ada untuk menarik kesimpulan (Supartini \& Hindarto, 2016).

\section{HASIL DAN PEMBAHASAN}

Berikut ini adalah pembahasan rancangan sistem pakar untuk mendeteksi kerusakan komputer.

\section{Pengumpulan data Pakar}

Proses pengumpulan data pakar terdiri dari dua tahap, yaitu wawancara langsung dengan para pakar, pengisian kuesioner oleh para pakar dan studi pustaka

A. Objek Pakar

1. Pakar pertama bernama Abdul Aziz Aminudin S.T jabatannya yaitu sebagai staf IT dan sudah bekerja selama 4 tahun

2. Pakar kedua bernama Agus Setiawan S.T jabatannya yaitu sebagai Staf IT dan sudah bekerja selama 9 tahun

3. Pakar ketiga bernama Dyan Pra Nugraha S.T jabatannya sebagai Staf IT. Dan sudah bekerja selama 8 tahun,selain itu juga pernah bekerja di salah satu perusahaan elektronik di daerah Karawang Jawa Barat

\section{B. Hasil Wawancara Pakar}

Pada tahap ini metode pengumpulan datanya dengan menggunakan kuesioner dan berikut adalah tabel skor pertanyaan yang didapat dari tiga pakar dimana pakar 1 adalah Abdul Aziz Aminudin S.T, pakar 2 adalah Agus Setiawan S.T, pakar 3 adalah Dyan Pra Nugraha S.T.

\section{Hasil Tabel Pakar}

Berdasarkan uraian tabel 2 di bawah, maka diperoleh basis pengetahuan tentang tabel pakar untuk mendeteksi kerusakan komputer. Berikut ini adalah susunan tabel pakar yang digunakan dalam sistem pakar ini:

Tabel 1 Gejala Kerusakan

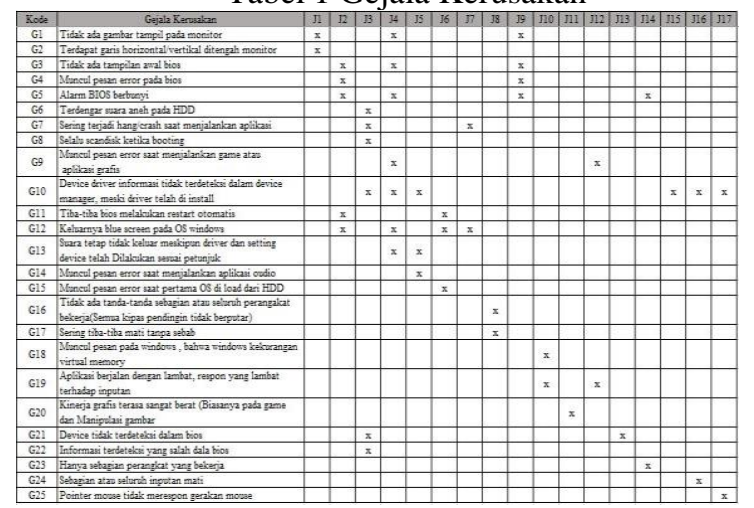

Sumber: (Penelitian, 2021) 


\section{Rule-rule Pada Pakar}

Dari data yang ada mengenai diagnosis kerusakan komputer yang mempunyai sistem aturan (rule) sehingga dalam penjelasan masalah untuk dilakukan diagnosa kerusakan untuk mendapatkan solusi yang baik dari beberapa penyebab kerusakan maka dibuatkan knowledge. Berikut ini adalah rule-rule pada sistem pakar untuk mendeteksi kerusakan komputer dengan menggunakan metode forward chaining :

Rule 1

IF Tidak ada gambar tertampil di monitor, AND Terdapat garis horisontal/vertical di tengah monitor,THEN Monitor Rusak.

Rule 2

IF Tidak ada tampilan awal bios,AND Muncul pesan eror pada bios,AND Alarm bios berbunyi,

AND Tiba-tiba OS melakukan restart otomatis,AND Keluarnya blue screen pada OS Windows,THEN Memori Rusak.

Rule 3

IF Terdengar suara aneh pada HDD, AND Sering Terjadi hang/crash saat menjalankan aplikasi, AND Selalu scandisk ketika booting, AND Device driver informasi tidak terdeteksi dalam device manager, meski driver telah di install,AND Device tidak terdeteksi dalam bios,AND Informasi deteksi yang salah dalam bios,THEN HDD Rusak

Rule 4

IF Tidak ada gambar tertampil di monitor,AND Tidak ada tampilan awal bios,AND alarm bios berbunyi,AND Muncul pesan eror saat menjalankan game atau aplikasi grafis,AND Device driver informasi tidak terdeteksi dalam device manager, meski driver telah di install,AND Keluarnya blue screen pada OS Windows,AND Suara tetap tidak keluar meskipun driver dan setting device telah dilakukan sesuai petunjuk, THEN VGA Rusak

Rule 5

IF Device driver informasi tidak terdeteksi dalam device manager, meski driver telah di install,AND Suara tetap tidak keluar meskipun driver dan setting device telah dilakukan sesuai petunjuk, AND Muncul pesan eror saat menjalankan aplikasi audio,THEN Sound Card Rusak

Rule 6

IF Tiba-tiba OS melakukan restart otomatis,AND Keluarnya blue screen pada OS Windows,AND Muncul pesan eror saat pertama OS di load dari HDD, THEN OS Bermasalah
Rule 7

IF Sering terjadi hang/crash

saat menjalankan aplikasi,AND Keluarnya blue screen pada OS Windows,THEN Aplikasi Rusak

Rule 8

IF Tidak ada tanda-tanda dari sebagian/seluruh perangkat bekerja (semua kipas pendingin tidak berputar), AND Sering tiba-tiba mati tanpa sebab, THEN PSU Rusak

Rule 9

IF Tidak ada gambar tertampil di monitor,AND Tidak ada tampilan awal bios,AND Muncul pesan eror pada bios,AND Alarm bios berbunyi,THEN Prosesor Rusak

Rule 10

IF Muncul pesan pada windows, bahwa windows kekurangan virtual memori, AND Aplikasi berjalan dengan lambat, respon yang lambat terhadap inputan,THEN Memory Kurang

Rule 11

IF Muncul pesan eror saat menjalankan game atau aplikasi grafis,AND Kinerja grafis terasa sangat berat (biasanya manipulasi game dan gambar),THEN Memory VGA Kurang

Rule 12

IF Aplikasi berjalan lambat, respon yang lambat terhadap inputan,THEN Clock Prosesor Kurang Tinggi

Rule 13

IF Device tidak terdeteksi dalam bios,THEN Kabel IDE Rusak

Rule 14

IF Alarm bios berbunyi,AND Hanya sebagian perangkat yang bekerja, THEN Kurang Daya Pada PSU

Rule 15

IF Device driver informasi tidak terdeteksi dalam device manager, meski driver telah di install,THEN Perangkat USB Rusak

Rule 16

IF Device driver informasi tidak terdeteksi dalam device manager, meski driver telah di install, AND Sebagian/seluruh karakter inputan mati, THEN Keyboard Rusak

Rule 17

IF Device driver informasi tidak terdeteksi dalam device manager, meski driver telah di install, AND Pointer mouse tidak merespon gerakan mouse, THEN Mouse Rusak. 


\section{E. Pohon Keputusan Pakar}

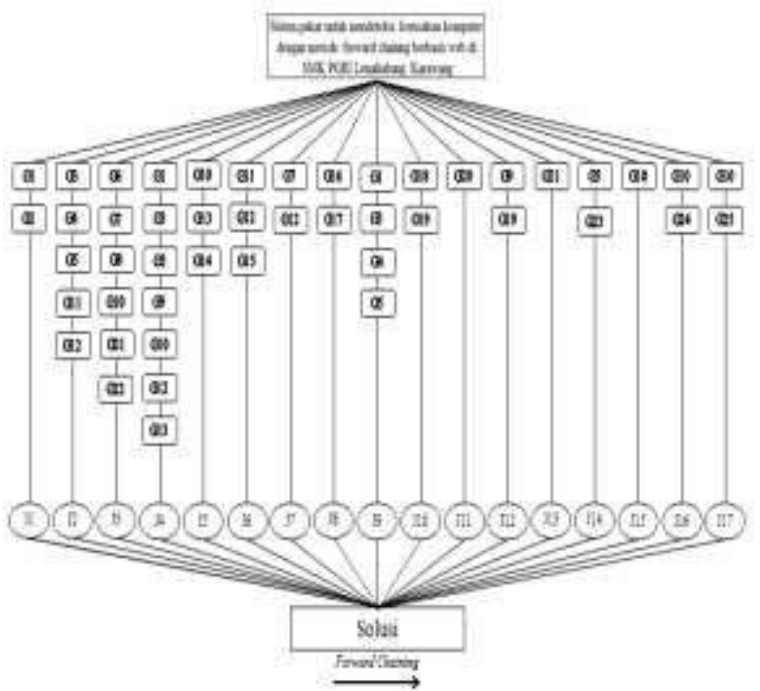

Sumber: (Penelitian, 2021)

Gambar 1. Pohon Keputusan

Pada gambar 1 merupakan tampilan pohon keputusan pakar yang digunakan pada sistem pakar sistem pakar untuk mendeteksi kerusakan komputer dengan metode forward chaining.

Gejala :

G1 : Tidak ada gambar tampil pada monitor

G2: Terdapat garis horizontal/vertikal ditengah monitor

Keterangan :

J1 : Monitor Rusak

Gejala :

G3 : Tidak ada tampilan awal bios G4 : Muncul pesan error pada bios G5 : Alarm BIOS berbunyi

G11 : Tiba-tiba bios melakukan restart otomatis G12

: Keluarnya blue screen pada OS windows Keterangan :

J2 : Memori Rusak

Gejala :

G6 : Terdengar suara aneh pada HDD

G7 : Sering terjadi hang/crash saat menjalankan aplikasi

G8 : Selalu scandisk ketika booting

G10 : Device driver informasi tidak terdeteksi dalam device manager, meski driver telah di install

G21 : Device tidak terdeteksi dalam bios

G22 : Informasi terdeteksi yang salah dalam bios Keterangan :

J3 : HDD Rusak

Gejala :

G1 : Tidak ada gambar tampil pada monitor

G3 : Tidak ada tampilan awal bios

G5 : Alarm BIOS berbunyi

G9 : Muncul pesan error saat menjalankan game atau aplikasi grafis

G10: Device driver informasi tidak terdeteksi dalam device manager, meski driver telah diinstall G12: Keluarnya blue screen pada OS windows

G13 : Suara tetap tidak keluar meskipun driverdan setting device telah Dilakukan sesuai petunjuk

Keterangan :

J4 : VGA Rusak

Gejala :

G10 : Device driver informasi tidak terdeteksi dalam device manager, meski driver telah diinstall

G13 : Suara tetap tidak keluar meskipun driverdan setting device telah Dilakukan sesuai petunjukG14 : Muncul pesan error saat menjalankan aplikasi audio Keterangan :

J5 : Sound Card Rusak

Gejala :

G11 : Tiba-tiba bios melakukan restart otomatis G12

: Keluarnya blue screen pada OS windows

G15 : Muncul pesan error saat pertama OS di load dari HDD

Keterangan :

J6 : OS Bermasalah

Gejala :

G7 : Sering terjadi hang/crash saat menjalankan aplikasi

G12 : Keluarnya blue screen pada OS windows Keterangan :

J7 : Aplikasi Crash/Rusak

Gejala :

G16 : Tidak ada tanda-tanda sebagian atau seluruh perangakat bekerja (Semua kipas pendingin tidak berputar)

G17 : Sering tiba-tiba mati tanpa sebab

Keterangan :

J8 : Power Suply Rusak

Gejala :

G1 : Tidak ada gambar tampil pada monitor

G3 : Tidak ada tampilan awal bios

G4 : Muncul pesan error pada bios

G5 : Alarm BIOS berbunyi

Keterangan :

J9 : Prosesor Rusak

Gejala :

G18 : Munculpesan pada windows,bahwa windows kekurangan virtual memory

G19 : Aplikasi berjalan dengan lambat, respon yang lambat terhadap inputan

Keterangan :

J10 : Memory Kurang

Gejala :

G20 : Kinerja grafis terasa sangat berat (Biasanya pada game dan Manipulasi gambar

Keterangan :

J11 : Memory VGA Kurang 
Gejala :

G9 : Muncul pesan error saat menjalankan game atau aplikasi grafis

G19 : Aplikasi berjalan dengan lambat, respon yang lambat terhadap inputan

Keterangan :

J12 : Clock Prosesor Kurang Tinggi

Gejala :

G21 : Device tidak terdeteksi dalam

biosKeterangan :

J13 : Kabel IDE/SATA/ATA Rusak

Gejala :

G5 : Alarm BIOS berbunyi

G23 : Hanya sebagian perangkat yang bekerja

Keterangan :

J14 : Kurang Daya Pada PSU

Gejala :

G10 : Device driver informasi tidak terdeteksi dalam device manager,meski driver telah di install Keterangan :

J15 : Perangakat USB rusak

Gejala :

G10 : Device driver informasi tidak terdeteksi dalam device manager,meski driver telah di install G24 : Sebagian atau seluruh inputan mati Keterangan :

J16 : Keyboard Rusak

Gejala :

G10 : Device driver informasi tidak terdeteksi dalam device manager,meski driver telah di install G25 : Pointer mouse tidak merespon gerakan mouse

Keterangan :

J17 : Mouse Rusak

\section{F. Rancangan Sistem Pakar}

A. Rancangan Entity Relationship Diagram (ERD)

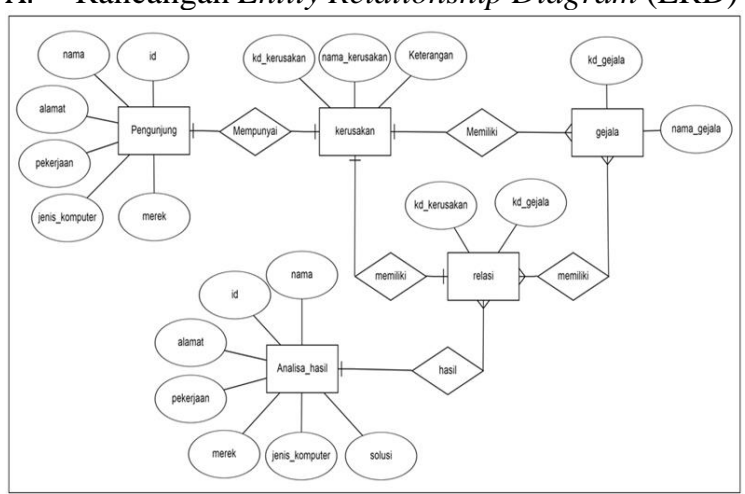

Sumber: (Penelitian, 2021)

Gambar 2. Entity relation Diagram

Paga Gambar 2 merupakan tampilan entity relation diagram yang menjelaskan beberapa Entity saling berhubungan dan mempunyai keterhubungan secara Cardinality $(1: 1,1: \mathrm{M}, \mathrm{M}: \mathrm{N})$.
B. Rancanagan Logical Record Structure (LRS)

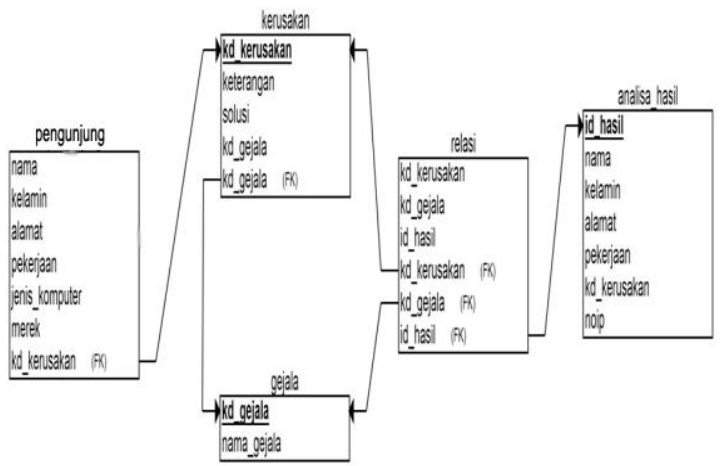

Gambar 3. Logical Record Sructure (LRS)

Pada Gambar 3 tampilan Logical Record Sructure yang menggambarkan basis data berupa relasi antar tabel yang mentransformasikan Entity Relationship Diagram ke Logical Record Structure melalui proses kardinalitas.

C. Rancangan Tampilan

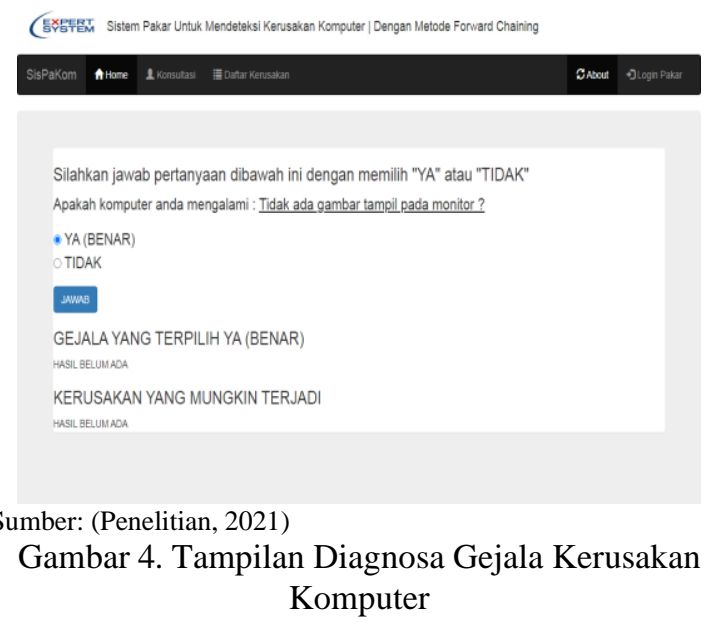

Pada Gambar 4 merupakan tampilan diagnosa gejala kerusakan komputer yang akan dijumpai olehuser. Tampilan ini menjelaskan tentang pertanyaan mengenai gejala-gejala kerusakan komputer dengan pilihan jawaban [Ya/Tidak] dengan kondisi sampai selesai.

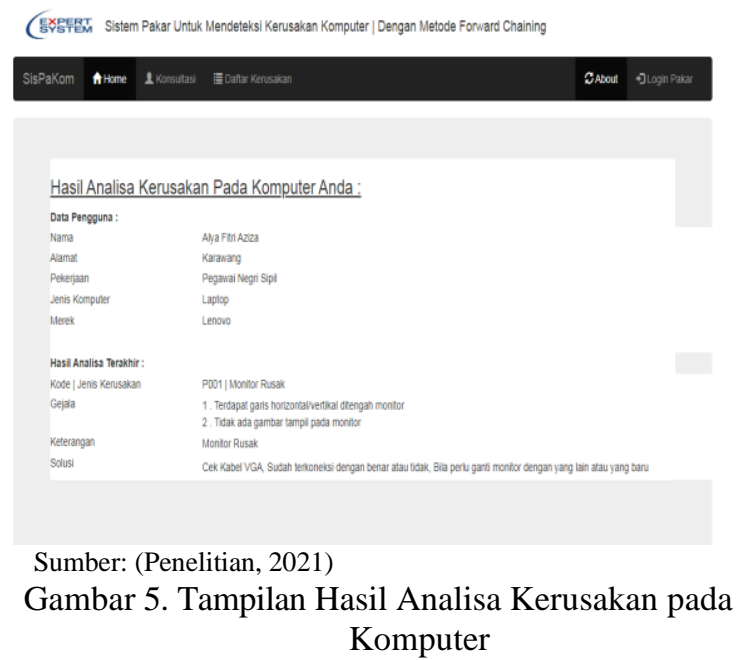


Pada Gambar 5 merupakan tampilan hasil analisa kerusakan pada komputer merupakan hasil dari analisa diagnosa kerusakan komputer. Tampilan ini berisi tentang hasil dari analisa kerusakan pada komputer dan akan memberikan solusi yang dapat dilakukan untuk memperbaik komputer.

\section{KESIMPULAN}

Berdasarkan permasalahan yang dibangun pada sistem pakar untuk mendeteksi kerusakan komputer dengan metode forward chaining berbasis web ini, maka dapat diambil beberapa kesimpulan yaitu sebagai berikut :

1. Dengan adanya sistem pakar ini dapat menambah informasi pengguna tentang pengetahuan dan pemahaman mengenai kerusakan pada Komputer.

2. Sistem pakar ini mampu meminimalisir ketergantungan pengguna terhadap pakar atau teknisi dalam hal identifikasi dan solusi awal kerusakan dan penanganan kerusakan pada komputer pengguna.

Metode forward chaining dapat dijadikan alternatif dalam melakukan analisa untuk mendeteksi kerusakan pada Komputer.

\section{REFERENSI}

Arisandi, D., \& Sari, I. P. (2021). Sistem Pakar dengan Fuzzy Expert.

David. (2017). PENERAPAN FUZZY MOORA PADA SISTEM PAKAR DIAGNOSA PENYAKIT DEMAM BERDARAH DENGUE. Seminar Nasional Teknologi Informasi Dan Multimedia 2017, 73-77.

Firman, A., Wowor, H. F., Najoan, X., Teknik, J., Fakultas, E., \& Unsrat, T. (2016). Sistem Informasi Perpustakaan Online Berbasis Web. E-Journal Teknik Elektro Dan Kompute, 5(2).

Imron, Afidah, M. N., Nurhayati, M. S., Sulistiyah, \& Fatmawati. (2019). Sistem Pakar Diagnosa Kerusakan Mesin Sepeda Motor Transmission Automatic dengan Metode Forward Chaining Studi Kasus: AHASS 00955 Mitra Perdana. Jurnal Ilmiah Universitas Batanghari Jambi, 19(3), 544-553 https://doi.org/10.33087/jiubj.v19i3.742

Ramadhanu, A., \& Gusrianto, R. (2021). ANAK MENGGUNAKAN METODE FORWARD CHAINING DENGAN BAHASA PEMPOGRAMAN PHP \& DATABASE. Jurnal Teknologi Dan Informasi Bisnis, 3(1), 254-258.

Rismayadi, A. A. (2016). PERANCANGAN APLIKASI SISTEM PAKAR DIAGNOSA KERUSAKAN HARDWARE KOMPUTER METODE FORWARD CHAINING. INFORMATIKA, 3(September), 219 - 233.

Shalahuddin, M., \& A.S., R. (2014). Rekayasa
Perangkat Lunak Terstruktur dan Berorientasi Objek. Bandung: Informatika Bandung.

Suhendra, Bangun, R. I., Aditya, F., Lestari, I. T., \& Yuniawati, D. (2015). SISTEM PAKAR DIAGNOSA GANGGUAN SAMBUNGAN TELEPON. Seminar Nasional Teknologi Informasi Dan Multimedia 2015, 6-8.

Supartini, W., \& Hindarto. (2016). Sistem Pakar Berbasis Web Dengan Metode Forward Chaining Dalam Mendiagnosis Dini Penyakit Tuberkulosis di JawaTimur. KINETIK, l(3), 147-154.

Taufik, A., \& Ermawati. (2017). Perancangan Sistem Informasi Pemesanan Pentas Seni Berbasis Web Pada Sanggar Seni Getar Pakuan Bogor. Indonesian Journal on Software Engineering Perancangan, 3(2), 1-7.

Widayanto, A., Pratmanto, D., Musyaffa, S. T., Informasi, S., Informasi, S., \& Informatika, T. (2018). SISTEM PAKAR DIAGNOSA KERUSAKAN KAMERA DSLR BERBASIS ANDROID. Jurnal Evolusi, 6(1), 33-40.

Yuswandi, \& Prasetyo, D. Y. (2019). SISTEM PAKAR DIAGNOSA PENYAKIT KEPITING BAKAU MENGGUNAKAN METODE FORWARD CHAINING. Jurnal Perangkat Lunak, 1, 22-32. 